\title{
Pemanfaatan Media Boneka Tangan untuk Meningkatkan Keterampilan Berbicara Anak Kelompok A3 TK Aba 26 Kota Malang
}

\author{
Jujum Jumaenah*, Usep Kustiawan, Leni Gonadi \\ Universitas Negeri Malang, Jl. Semarang No. 5 Malang, Jawa Timur, Indonesia \\ *Penulis korespondensi, Surel: jujumjumaenah28@gmail.com
}

Paper received: 2-1-2021; revised: 23-1-2021; accepted: 30-1-2021

\begin{abstract}
Speaking is the child's ability to express ideas, or thoughts to others through the medium of spoken language. The ability to speak in the A3 TK ABA 26 city in Malang City has not developed optimally, as evidenced from 31 children, there are 16 children who have not been able to reach their speech development. The purpose of this study is to describe the use of hand puppet media to improve speaking skills and describe improvement in A3 speaking abilities. ABA 26 TK Malang City. The type of research used is Classroom Action Research. The research subjects were an A3 group with 31 children. Methods of collecting data through observation, interviews, and documentation. The research instruments used in the form of observation sheets attainment of children's speaking skills, teacher activity observation sheets and interview guideline sheets. Data analysis techniques are qualitative and quantitative data analysis techniques. The results of the study addressed the increase in scores in Cycle I by $42.3 \%$ and Cycle II by $80.78 \%$. Based on these results it can be concluded that the use of hand puppet media with storytelling activities can improve the speaking ability of children in the A3 TK ABA 26 group in Malang City. The suggestion of this research is that the teacher should use hand puppet media as one of the media to improve children's speaking skills, it is hoped that the school can provide media that can support children's development, for other researchers, it is suggested to try to develop other aspects of development with hand puppet media.
\end{abstract}

Keywords: speaking; storytelling; hand puppets

\begin{abstract}
Abstrak
Berbicara adalah kemampuan anak untuk mengeluarkan ide, gagasan ataupun pikirannya kepada orang lain melalui media bahasa lisan. Kemampuan berbicara pada kelompok A3 TK ABA 26 Kota Malang belum berkembang secara optimal, terbukti dari 31 anak terdapat 16 anak yang belum mampu mencapai perkembangan berbicaranya.Tujuan penelitian ini untuk mendeskripsikan pemanfaatan media boneka tangan dalam meningkatkan kemampuan berbicara dan mendeskripsikan peningkatan kemampuan berbicara anak kelompok A3 TK ABA 26 Kota Malang. Jenis penelitian yang digunakan yaitu Penelitian Tindakan Kelas. Subjek penelitian kelompok A3 dengan jumlah 31 anak. Metode pengumpulan data melalui observasi, wawancara dan dokumentasi. Instrumen penelitian yang digunakan berupa lembar observasi ketercapaian kemampuan berbicara anak, lembar observasi aktivitas guru dan lembar pedoman wawancara. Teknik analisis data yaitu teknik analisis data kualitatif dan kuantitatif. Hasil penelitian menunjukkan peningkatan skor pada Siklus I sebesar 42,3\% dan Siklus II sebesar 80,78\%. Berdasarkan hasil tersebut dapat disimpulkan bahwa pemanfaatan media boneka tangan dengan kegiatan bercerita dapat meningkatkan kemampuan berbicara anak kelompok A3 TK ABA 26 Kota Malang. Saran penelitian ini yaitu sebaiknya guru menggunakan media boneka tangan sebagai salah satu media untuk meningkatkan kemampuan berbicara anak, diharapkan sekolah dapat menyediakan media yang dapat mendukung perkembangan anak, bagi peneliti lain disarankan untuk mencoba mengembangkan aspek perkembangan lain dengan media boneka tangan.
\end{abstract}

Kata kunci: berbicara; bercerita; boneka tangan 


\section{Pendahuluan}

Berbicara sangat digemari anak usia dini, apalagi ketika mereka membicarakan dirinya dan pengalamannya, dalam hal ini tentunya dorongan dan dukungan guru sangat berpengaruh terhadap peningkatkan perkembangan berbicaranya, selain itu guru juga harus memberikan kesempatan pada anak untuk mengikuti berbagai aktivitas misalnya dengan kegiatan bercerita, bernyanyi, mengikuti drama dan sebagainya. Keterampilan berbicara termasuk kedalam aspek bahasa yaitu mengekspresikan bahasa. Bahasa di pendidikan anak usia dini dikenal sebagai salah satu aspek perkembangan dari enam aspek perkembangan yang harus ditingkatkan. Upaya guru dalam meningkatkan bahasa anak di sekolah yaitu dengan menggunakan berbagai media permainan, melalui kegiatan bernyanyi, bercakap-cakap dan sebagainya. Vygotsky dalam Nisa, (2018) menyatakan bahwa "Language is critical for cognitive development. Language provide a means for expressing ideas and asking question and it provides the categories and concept for thinking". Bahasa merupakan alat untuk mengekspresikan ide dan bertanya, bahasa juga menghasilkan konsep dan kategori-kategori untuk berfikir. Hal tersebut selaras dengan Susanto dalam Zuliana (2018) menyatakan bahwa bahasa adalah alat untuk berfikir, mengekspresikan diri dan berkomunikasi. Anak yang terampil dalam berbahasa akan lebih mudah mengekspresikan ide-ide dan gagasannya di depan umum tanpa merasa malu atau tidak percaya diri ketika menyampaikannya.

Salah satu perkembangan dalam aspek bahasa yaitu kemampuan berbicara. Berbicara adalah kemampuan seseorang untuk mengeluarkan ide, gagasan ataupun pikirannya kepada orang lain melalui media bahasa lisan (Sutrisna, 2017). Tarigan dalam Mardiana, (2017) berbicara merupakan kemampuan mengucapkan bunyi-bunyi artikulasi atau kata-kata untuk mengekspresikan, menyatakan serta menyampaikan pikiran, gagasan dan perasaan. Supriyono, (2008) menyatakan bahwa berbicara merupakan kegiatan berbahasa yang bersifat praktis. Sedangkan menurut Suhendar dalam Supriyana, (2008) menyatakan bahwa berbicara adalah proses perubahan wujud pikiran atau perasaan menjadi wujud ujaran. Berdasarkan paparan para ahli di atas tentang pengertian berbicara maka dapat disimpulkan bahwa berbicara merupakan kemampuan anak dalam mengucapkan bunyi-bunyi artikulasi atau katakata, mengekspresikan pikiran, gagasan, perasaan maupun ide-ide yang akan disampaikan kepada guru, teman, orangtua maupun orang-orang yang berada di sekitarnya.

Bertambahnya usia anak akan mempengaruhi perkembangan dan karakteristik berbicaranya. Berikut ini akan dijelaskan tentang perkembangan berbicara anak kelompok A dengan kriteria usia 4-5 tahun. Karakteristik kemampuan berbicara anak usia 4-5 tahun. Dhieni, Fridana, Muis, Yarmi \& Wulan, (2013) menyatakan karakteristik perkembangan berbicara anak usia 4-5 tahun yaitu: 1) memahami beberapa kata sambung, 2) mendefinisikan benda yang sama, 3) menanyakan definisi kata-kata, 4) menunjuk dada, tumit, pergelangan kaki dan rahang, 5) menanamkan warna hijau, kuning, jingga dan ungu, 6) memahami perbandingan, 7) mengikuti tiga perintah yang tidak berhubungan dengan urutan yang benar, 8) mengajukan pertanyaan kapan dan mengapa, 9) memahami urutan kejadian saat diceritakan, 10) menggambarkan perbedaan benda- benda, 11) menggambarkan persamaan benda-benda, 12) menamakan warna coklat, hitam, merah muda, putih dan abu-abu, 13) membicarakan tentang hubungan sebab akibat dengan menggunakan kata "sehingga", 14) menggunakan kata kerja dan kata benda, 15) menunjukan beraneka ragam penggunaan bahasa: mendapat dan memberikan keterangan, mengekspresikan gagasan dan pendapat. Jika karakteristik tersebut sudah tercapai oleh anak maka perkembangan bahasanya dapat dikatakan sesuai dengan tingkat usianya. 
Karakteristik kemampuan berbicara anak usia 4-5 tahun yang dipaparkan oleh ahli diatas selaras dengan Peraturan Menteri Republik Indonesia Nomor 137 Tahun 2014. Karakteristik perkembangan berbicara anak usia 4-5 tahun yaitu: 1) mengulang kalimat sederhana, 2) bertanya dengan kalimat yang benar, 3) menjawab pertanyaan sesuai pertanyaan, 4) mengungkapkan perasaan dengan kata sifat "baik, senang, nakal, pelit, baik hati, berani, baik, jelek dan sebagainya", 5) menyebutkan kata-kata yang dikenal, 6) mengutarakan pendapat kepada orang lain, 7) menyatakan alasan terhadap sesuatu yang diinginkan atau ketidaksetujuan, 8) menceritakan kembali cerita atau dongeng yang pernah didengar, 9) memperkaya perbendaharaan kata dan 10) berpartisipasi dalam percakapan. Artinya jika perkembangan berbicara anak sudah sesuai dengan karakteristik yang dipaparkan di atas maka kemampuan berbicara anak sudah berkembang secara optimal, tapi jika salah satu atau beberapa karakteristik tersebut belum tercapai oleh anak, maka diperlukan pengkajian ulang untuk membantu anak dalam mencapai perkembangan berbicaranya. Perkembangan bahasa anak usia 4 tahun memiliki perbendaharaan kata sekitar 4.000 sampai 6.000 kata dan mereka banyak berbicara dalam kalimat lima sampai enam kata. Sedangkan anak usia 5 tahun perkembangan bahasanya akan terus meningkat sekitar 5.000 sampai 8.000 kata. Artinya kemampuan berbicara anak akan terus meningkat seiring dengan bertambahnya usia anak (Seefeldt \& Wasik, 2008). Jika salah satu atau beberapa karakteristik tersebut belum tercapai oleh anak, maka diperlukan pengkajian ulang untuk membantu anak dalam mencapai perkembangan berbicaranya.

Perkembangan berbicara juga dipengaruhi oleh faktor-faktor yang mendukung diantaranya latar belakang keluarga, lingkungan sekitar, kemampuan otot dan motivasi. Dhieni, Fridana, Muis, Yarmi \& Wulan, (2013) peningkatan kemampuan berbicara anak dipengaruhi oleh beberapa faktor yaitu; 1) Faktor neurologi, mencakup perkembangan kognitif, strategi memproses informasi, kemampuan output motor serta perkembangan sosial dan motivasi, 2) Faktor struktural dan fisiologi, mencakup kemampuan sensorik, kemampuan oromuscular dan mekanisme transmisi bahasa dan 3) Faktor lingkungan, mencakup sosial budaya, pengalaman dan konteks fisik. Faktor lingkungan sangat berpengaruh terhadap perkembangan kemampuan berbicara anak, karena apabila anak mendapatkan stimulus dan motivasi dari orang-orang disekitarnya maka kemampuan berbicara anak akan berkembang secara optimal.

Berdasarkan observasi yang dilakukan oleh peneliti pada 30 Juli 2018 sampai 17 September 2018 dan dari hasil wawancara guru kelas yang dilakukan pada 19 Januari 2019 di TK ABA 26 Kota Malang pada kelompok A3. Peneliti mendapatkan data bahwa dari 31 anak terdapat 48,3\% (15 anak) sudah berkembang aspek berbicaranya dan terdapat 51,6\% (16 anak) cenderung diam dan kurang aktif berbicara ketika kegiatan pembelajaran di dalam kelas, selain itu anak belum berani bertanya ataupun mengungkapkan pendapatnya ketika kegiatan belajar. Data dan keterangan tersebut menunjukan bahwa keterampilan bicara anak kelompok A3 TK ABA 26 Kota Malang belum berkembang secara optimal.

Permasalahan di atas disebabkan oleh beberapa faktor yaitu saat guru menjelaskan di depan kelas anak bermain sendiri, anak kurang berperan aktif dalam pembelajaran, fasilitas dan media pembelajaran yang kurang dioptimalkan. Melalui masalah tersebut maka peneliti memberikan solusi berupa pemanfaatan media boneka tangan dengan kegiatan bercerita pada anak kelompok A3 TK ABA 26 Kota Malang. Tujuannya yaitu dengan memanfaatkan media boneka tangan anak bisa berpartisipasi secara aktif dalam kegiatan pembelajaran, anak bisa 
lebih leluasa dalam mengembangkan kemampuan berbicaranya dengan kegiatan bercakapcakap, tanya jawab, menjawab pertanyaan, mengungkapkan perasaan dan menceritakan kembali secara bebas sesuai dengan kemampuannya.

Boneka tangan termasuk dari berbagai jenis media boneka. Perbedaannya hanya pada cara memainkannya. Anak-anak memiliki daya imajinasi yang tinggi sehingga terkadang boneka yang ia miliki dijadikan sebagai teman untuk bercakap-cakap. Media boneka tangan adalah boneka yang ukurannya lebih besar dari boneka jari dan bisa dimasukan ke tangan, jari tangan dijadikan pendukung gerakan tangan dan kepala. Gerakan boneka didukung oleh suara yang bersumber dari pemain boneka, sehingga seolah-olah boneka tangan hidup dan dapat bercakap-cakap dengan anak (Sulianto dkk, (2014). Sedangkan menurut Musfiroh, (2005) menyatakan bahwa boneka tangan yaitu terbuat dari kain yang dibentuk meyerupai wajah dan bentuk tubuh dari berbagai macam sifat. Artinya media boneka tangan bisa dibuat dengan berbagai karakter yang disesuaikan dengan sifat atau ciri-ciri seorang tokoh.

Fungsi media boneka tangan yaitu dapat digunakan sebagai alat peraga dalam kegiatan pembelajaran atau dijadikan sebagai sarana hiburan dalam pementasan seni. Sulianto, Untari \& Yulianti, (2014) menyatakan bahwa fungsi media boneka tangan yaitu sebagai media perantara yang digunakan untuk melibatkan anak dalam cerita yang sedang disampaikan, meningkatkan imajinasi anak dan dapat merangsang anak untuk menyampaikan ide yang ada pada dirinya. Daryanto, (2013) media boneka tangan memiliki manfaat yaitu dapat mengembangkan imajinasi dan kreativitas anak dalam suasana gembira. Dhieni, Fridana, Muis, Yarmi \& Wulan dalam Sariguam (2017) menyatakan bahwa fungsi media boneka tagan yaitu digunakan untuk pentas sandiwara, meningkatkan imajinatif dan mendorong anak untuk menggunakan bahasa. Boneka tangan dapat menjadi stimulus agar anak mau berbicara menyampaikan ide, gagasan atau bercerita. Berdasarkan penjelasan beberapa ahli di atas maka dapat disimpulkan bahwa media boneka khususnya di pendidikan anak usia dini yaitu memiliki fungsi sebagai alat untuk menunjang atau pelengkap dalam pembelajaran, mengembangkan aspek bahasa khususnya pada aspek berbicara, kognitif atau daya pikir, meningkatkan daya imajinasi, sebagai mainan ataupun sarana hiburan bagi anak-anak.

\section{Metode}

Penelitian ini menggunakan model penelitian tindakan kelas yang dikembangkan oleh Arikunto, Suharjono \& Supardi, (2014:16) penelitian menggunakan model kolaborasi karena dalam pelaksanaannya terdapat kerjasama antara peneliti dan guru. Pihak yang melakukan tindakan adalah peneliti sedangkan yang melakukan pengamatan terhadap berlangsungnya proses tindakan adalah guru kelompok A3 TK ABA 26 Kota Malang. Penelitian tindakan kelas secara garis besar terdapat empat tahapan yaitu; 1) perencanaan, 2) pelaksanaan, 3) pengamatan dan 4) refleksi.

Penelitian ini menggunakan model penelitian tindakan kelas yang dikembangkan oleh Arikunto, Suharjono \& Supardi, (2014:16) penelitian menggunakan model kolaborasi karena dalam pelaksanaannya terdapat kerja sama antara peneliti dan guru. Pihak yang melakukan tindakan adalah peneliti sedangkan yang melakukan pengamatan terhadap berlangsungnya proses tindakan adalah guru kelompok A3 TK ABA 26 Kota Malang. Penelitian tindakan kelas secara garis besar terdapat empat tahapan yaitu; 1) perencanaan, 2) pelaksanaan, 3) pengamatan dan 4) refleksi.Tahap perencanaan peneliti membuat RPPH, menyiapkan dan membuat kegiatan pembelajaran, membuat instrumen penelitian dan menjelaskan tentang 
apa, mengapa, kapan, dimana, oleh siapa dan bagaimana tindakan tersebut dilakukan. Tahap pelaksanaan dilakukan secara bersiklus, dalam satu siklus terdapat dua kali pertemuan, pada tahap ini peneliti sebagai pihak yang melakukan praktik atau yang menerapkan media boneka tangan dalam pembelajaran. Tahap pengamatan dilakukan oleh guru kelas A3 TK ABA 26 Kota Malang dan yang terakhir yaitu tahap refleksi atau meninjau kembali kegiatan penelitian yang sudah dilaksanakan, dilakukan oleh peneliti dan guru kelas A3 TK ABA 26 Kota Malang.

Lokasi penelitian di TK ABA 26 Kota Malang, dilaksanakan pada semester II tahun ajaran 2018/2019 pada Maret sampai September 2019. Subjek penelitian adalah anak kelompok A3 TK ABA 26 Kota Malang dengan jumlah 31 anak. Objek penelitian yaitu kemampuan berbicara.

Pengumpulan data menggunakan teknik observasi, wawancara dan dokumentasi. Teknik Observasi pada penelitian ini digunakan untuk mengamati aktivitas guru, anak dan proses berjalanya kegiatan pembelajaran di dalam kelas, dilakukan dari awal hingga evaluasi pembelajaran. Teknik wawancara digunakan untuk mewawancarai guru kelas tentang sikap dan keaktifan anak ketika mengikuti kegiatan bercerita dengan media boneka tangan, selain itu wawancara juga digunakan untuk mengetahui kesulitan atau hambatan-hambatan yang terjadi selama kegiatan penelitian berlangsung. Sedangkan teknik dokumentasi digunakan untuk mendokumentasikan langkah-langkah kegiatan pelaksanaan penelitian di dalam kelas, berupa foto, penilaian hasil perkembangan anak dan catatan penelitian. Instrumen yang digunakan yaitu lembar observasi ketercapaian kemampuan berbicara anak lembar observasi aktivitas guru dan lembar pedoman wawancara. Data hasil observasi, wawancara dan dokumentasi dianalisis secara deskriptif kualitatif dan deskriptif kuantitatif. Data kualitatif digunakan untuk mendeskripsikan hasil dari kegiatan penelitian yang dilaksanakan melalui siklus I dan siklus II. Sedangkan data kuantitatif digunakan untuk mengetahui peningkatan tentang ketercapaian perkembangan kemampuan berbicara anak, melalui rumus penelitian dengan menghitung score atau nilai yang telah ditentukan.

\section{Hasil dan Pembahasan}

\subsection{Hasil}

Berdasarkan hasil observasi yang didapatkan peneliti pada pra tindakan, siklus I dan siklus II di kelompok A3 TK ABA 26 Kota Malang. Bahwa dengan memanfaatkan media boneka tangan dapat meningkatkan kemampuan berbicara anak. Hal tersebut dapat dilihat melalui pemaparan hasil yang diperoleh dari pra tindakan, siklus I dan siklus II yaitu sebagai berikut.

Penelitian pra tindakan dilaksanakan pada 5-8 Februari 2019 di kelas A3 TK ABA 26 Kota Malang dengan jumlah anak yang hadir 27 dari 31 anak. Kegiatan awal pembelajaran diawali dengan senam ceria di halaman sekolah bersama seluruh guru kelas A, setelah selesai anak-anak langsung masuk kelas masing-masing. Kegiatan berikutnya anak melakukan kegiatan Al Islam, shalat dhuha dan setelah itu istirahat pertama makan dan minum. Selesai istirahat anak-anak langsung diminta duduk rapi untuk melaksanakan kegiatan pembelajaran, tema pada hari itu adalah kendaraan, sub tema kendaraan darat. Guru memperlihatkan gambar mobil dan motor kemudian bercerita tentang tema itu. Setelah itu anak-anak dibagi menjadi dua kelompok, kelompok satu mengerjakan LK mewarnai gambar, kelompok dua menggunting gambar mobil. 
Setelah semua kegiatan selesai anak istirahat kedua bermain di dalam dan luar kelas, makan dan minum, terakhir guru melakukan refleksi dan penutup. Hasil dari penelitian pra tindakan yaitu dari 21 anak yang mencapai kemampuan berbicara hanya 6 anak, sedangkan 21 anak belum dapat mencapai perkembangan tersebut. Rata-rata kelas pada pra tindakan yaitu 50,23 . Sedangkan persentase capaian perkembangan kelas pada pra tindakan yaitu $22,22 \%$. Berdasarkan hasil tersebut maka dapat disimpulkan bahwa kemampuan berbicara anak masih sangat rendah.

Tabel 1. Capaian Kemampuan Berbicara Anak Siklus I

\begin{tabular}{lcc}
\hline \multicolumn{1}{c}{ Pertemuan } & Skor Rata-rata & Capaian Perkembangan Kelas \\
\hline Siklus I Pertemuan Pertama & 61,51 & $30,76 \%$ \\
Siklus I Pertemuan kedua & 72 & $53,84 \%$ \\
Rata-rata & 66,75 & $42,3 \%$ \\
\hline
\end{tabular}

Berdasarkan tabel 1 maka dapat dipaparkan bahwa pelaksanaan penelitian pada siklus I menunjukkan bahwa pada siklus I pertemuan pertama diperoleh skor capaian perkembangan kelas sebesar 30,76\%. dan pada siklus I pertemuan kedua diperoleh skor capaian perkembangan kelas sebesar 53,84\%. Hasil skor rata-rata kemampuan berbicara anak pada siklus I sebesar 66,75 dan hasil rata-rata perkembangan kelas sebesar 42,3\%. Karena skor pencapaian kelas belum memenuhi kriteria yang telah ditentukan yaitu sekurang-kurangnya mencapai $75 \%$ dari jumlah anak, maka perlu dilaksanakan tindakan penelitian selanjutnya untuk mencapai kriteria yang ditentukan.

Tabel 2. Capaian Kemampuan Berbicara Anak Siklus II

\begin{tabular}{lcc}
\hline \multicolumn{1}{c}{ Pertemuan } & Skor Rata-rata & Capaian Perkembangan Kelas \\
\hline Siklus II Pertemuan Pertama & 79,89 & $69,56 \%$ \\
Siklus II Pertemuan kedua & 87,58 & $92 \%$ \\
Rata-rata & 83,73 & $80,78 \%$ \\
\hline
\end{tabular}

Berdasarkan tabel 2 diatas maka dapat dipaparkan bahwa pelaksanaan penelitian pada siklus II menunjukkan bahwa pada siklus II pertemuan pertama skor rata-rata yaitu 79,89 dan siklus II pertemuan pertama capaian perkembangan kelas dengan skor 69,56\%. Jumlah persentase rata-rata pada siklus II pertemuan kedua yaitu 87,58 dan siklus II pertemuan kedua capaian perkembangan kelas dengan skor 92\%. Hasil skor rata-rata kemampuan berbicara anak pada siklus II sebesar 83,73 dan hasil rata-rata capaian perkembangan kelas sebesar 80,78\%. Hasil tersebut menunjukkan bahwa ketuntasan secara keseluruhan kemampuan berbicara anak kelompok A3 TK ABA 26 Kota Malang telah berhasil dengan baik karena persentase ketuntasan telah melebihi dari kriteria minimal yang ditentukan yaitu $75 \%$.

\subsection{Pembahasan}

Pelaksanaan penelitian menggunakan media boneka tangan dilakukan dengan 3 tahap yaitu tahap pra tindakan, siklus I dan siklus II. Setiap siklus dilaksanakan dua pertemuan. Pelaksanaan pra tindakan dilaksanakan pada 5-8 Februari 2019, siklus I pertemuan pertama dilaksanakan pada 19 Maret 2019 dan pertemuan kedua dilaksanakan pada 25 Februari 2019. Pelaksanaan siklus II pertemuan pertama yaitu pada 27 Februari 2019 dan pertemuan kedua pada 04 Maret 2019. Pelaksanaan penelitian pada siklus I pertemuan pertama jumlah anak 
yang hadir yaitu 23 dari 31 anak dan pertemuan kedua anak yang hadir sebanyak 25 dari 31 anak.

Pelaksanaan siklus I pertemuan pertama peneliti membahas tema lingkunganku dan sub tema menjaga pohon, kegiatan lain selain bercerita menggunakan media boneka tangan yaitu membuat gambar kolase pohon dari kapas. Pertemuan kedua peneliti membahas tema lingkunganku dengan sub tema tolong menolong, kegiatan lain selain bercerita menggunakan media boneka tangan yaitu menggunting gambar kemudian ditempel dan mewarnai gambar. Pelaksanaan siklus II pertemuan pertama peneliti membahas tema diriku dengan sub tema kesehatan dan kebersihan diri, kegiatan pendukung yaitu anak menghubungkan gambar tentang kebersihan tubuh dan mewarnai. Pertemuan kedua membahas tema diriku dengan sub tema jujur, kegiatan pendukung yaitu mencocok gambar dan mewarnai gambar.

Pemanfaatan media boneka tangan dalam pelaksanaannya dilakukan beberapa langkah mulai dari awal kegiatan, hingga akhir kegiatan. Langkah-langkah penerapan media boneka tangan dengan kegiatan bercerita untuk meningkatkan keterampilan berbicara pada penelitian ini yaitu; 1) Menyiapkan tempat untuk bercerita dan mengerjakan LK, 2) Pada kegiatan inti pembelajaran peneliti melakukan apersepsi kemudian mengajak anak untuk bercakap-cakap terlebih dahulu mengenai tema pada hari itu, 3) Peneliti menjelaskan kegiatan yang akan dilakukan anak pada hari itu, 4) Menjelaskan cara mengerjakan LK yang telah disediakan oleh guru pada hari itu, 5) Membagi anak menjadi dua kelompok. Kelompok satu mengerjakan LK dan kelompok dua mengikuti kegiatan bercerita, 6) Meminta bantuan guru untuk mengarahkan anak yang sudah mengerjakan LK untuk mengikuti kegiatan bercerita dan sebaliknya mengarahkan anak yang sudah mengikuti kegiatan bercerita untuk mengerjakan LK, 7) Merubah penampilan boneka dengan mengganti bajunya ketika akan tampil, 8) Sebelum bercerita, peneliti memberitahukan kepada anak tentang judul cerita, nama dan karakter tokoh di dalam isi cerita. Judul cerita disesuaikan dengan tema ada hari itu, 9) Mengali pengetahuan anak tentang judul cerita, sebelum guru menyampaikan isi cerita, 10) Peneliti bercerita menggunakan media boneka tangan, saat kegiatan bercerita berlangsung, guru menyelingi dengan pertanyaan-pertanyaan terkait isi cerita, memberi kesempatan kepada anak untuk mengungkapkan pendapatnya dan diselingi dengan humor yang diperagakan oleh boneka sehingga kegiatan bercerita tidak membosankan, 11) Peneliti memberikan kesempatan kepada semua anak untuk mencoba bercerita di depan kelas dengan media boneka tangan, 12) Peneliti memberikan rewards berupa pujian dan pemberian stiker, 13) Setelah semua kegiatan inti terlaksana, peneliti memberikan kesempatan kepada anak A3 yang ingin bercerita bebas atau bercerita mengenai pengalamannya menggunakan media boneka tangan dan 14) Kegiatan akhir peneliti memberikan penguatan dan pesan-pesan moral serta menanyakan perasaan anak pada hari itu. Setelah semua kegiatan dari awal hingga akhir maka anak-anak diminta untuk bersiap-siap untuk pulang. Langkah-langkah tersebut sejalan dengan pendapat Soeparno dalam Yunita, (2014:38) yang telah dijelaskan pada kajian teori di bab II. Setelah penelitian dilaksanakan kenyataanya langkah-langkah yang digunakan sedikit berbeda. Perbedaannya yaitu langkah-langkah yang diterapkan oleh Soeparno hanya sekedar garis besarnya saja, akan tetapi setelah peneliti mempraktekkan langsung pemanfaatan media boneka tangan dengan kegiatan bercerita pada kelompok A3 TK ABA 26 Kota Malang hasilnya yaitu langkah- langkah penerapannya lebih banyak atau lebih terperinci, mulai dari awal pembelajaran sampai akhir pembelajaran. 
Peningkatan kemampuan berbicara anak kelompok A3 TK ABA 26 Kota Malang mengalami peningkatan. Pelaksanaan penelitian pada siklus I mendapatkan skor rata-rata kemampuan berbicara sebesar 66,51 dan pada siklus II sebesar 83,73, hasil tersebut menunjukkan peningkatan sebesar 75,24. Sedangkan rata-rata persentase capaian keberhasilan kelas pada siklus I sebesar $42,3 \%$ dan pada siklus II sebesar $80,78 \%$, hasil tersebut menunjukan peningkatan sebesar $61,54 \%$. Dengan adanya peningkatan tersebut maka peneliti dan guru kelas A3 TK ABA 26 Kota Malang mengambil kesimpulan bahwa pemanfaatan media boneka tangan dapat meningkatkan kemampuan berbicara anak. Hal tersebut sesuai dengan pendapat Reidmiller dalam Maharani (2008:103) menyatakan bahwa Penggunaan boneka tangan dapat memberikan bantuan untuk berbicara di depan umum, terutama pada anak yang pemalu atau penakut. Sedangkan Dhieni dkk dalam Sariguam (2017:12) menyatakan bahwa fungsi media boneka tangan yaitu digunakan untuk pentas sandiwara, meningkatkan imajinatif dan mendorong anak untuk menggunakan bahasa. Mengungkapkan bahasa yaitu termasuk dalam mengekspresikan bahasa yang berarti dilakukan secara lisan atau disebut dengan berbicara.

\section{Simpulan}

Berdasarkan penelitian dalam pemanfaatan media boneka tangan melalui kegiatan bercerita untuk meningkatkan kemampuan berbicara anak kelompok A3 TK ABA 26 Kota Malang, dengan indikator 1) Anak dapat bertanya dengan kaliamat yang benar, 2) Anak dapat menjawab pertanyaan yang diajukan oleh guru, 3) Anak dapat mengungkapkan perasaannya pada hari itu dan 4) Anak dapat menceritakan kemabil cerita yang disampaikan oleh guru. Maka menunjukkan bahwa tindakan penelitian dengan menerapkan media boneka tangan pada kelompok A3 TK ABA 26 Kota Malang dapat meningkatkan kemampuan bahasa anak khususnya pada aspek berbicara. Kesimpulan dari penelitian ini yaitu Pemanfaatan media boneka tangan dapat meningkatkan kemampuan berbicara anak kelompok A3 TK ABA 26 Malang, dengan kegiatan bercerita. Kegiatan bercerita dilakukan di dalam kelas dan diperkaya dengan kegiatan-kegiatan lain yang dapat mengembangkan aspek selain bahasa, misalnya membuat gambar kolase, mencocok, mengunting dan mewarnai, sehingga anak tidak merasa bosan dengan pembelajaran yang di laksanakan.

Melalui pemanfaatan media boneka tangan pada pembelajaran, membuat anak-anak lebih fokus dan antusias dalam mengikuti pembelajaran, hal tersebut karena media boneka tangan yang peneliti gunakan memiliki ciri yang unik sehingga menarik perhatian anak. Terdapat beberapa faktor penghambat dalam penerapan media boneka tangan yaitu kegiatan pembelajaran memakan waktu yang cukup banyak, media boneka tangan terlalu besar sehingga tidak sesuai dengan ukuran tangan anak, memerlukan banyak guru untuk membantu proses pembelajaran. Peningkatan kemampuan berbahasa khususnya pada aspek berbicara anak kelompok A3 TK ABA 26 Malang melalui pemanfaatan media boneka tangan dengan kegiatan bercerita, terbukti meningkat dilihat dari respon anak-anak ketika proses pembelajaran berlangsung yaitu 1) Anak-anak sangat antusias untuk bercerita di depan kelas menggunakan media boneka tangan, 2) Anak-anak lebih fokus dalam memperhatikan penjelasan guru, 3) Proses pembelajaran lebih kondusif dan 4) Rata-rata capaian perkembangan kelas Rata-rata persentase capaian keberhasilan kelas pada siklus I sebesar $42,3 \%$ dan pada siklus II sebesar $80,78 \%$. Peningkatan dari siklus I sampai siklus II sebesar $61,54 \%$. Hasil tersebut menunjukkan bahwa kemampuan bicara anak berkembang sangat baik, karena persentase yang diperoleh melebihi kriteria yang telah ditentukan yaitu 75\%. 
Berdasarkan pelaksanaan penelitian yang telah dilakukan maka berikut di bawah ini saran- saran yang dapat dijadikan sebagai acuan untuk perbaikan dan kemajuan penelitian mendatang yaitu:1) Guru diharapkan menggunakan media boneka tangan sebagai salah satu alat peraga yang bisa dimanfaatkan semaksimal mungkin, karena dilihat dari hasil penelitian terbukti bahwa media boneka tangan dengan kegiatan bercerita dapat meningkatkan keterampilan berbicara anak. Beri kesempatan dan kebebasan pada anak untuk berperan aktif dalam pembelajaran khususnya pada kegiatan bercerita, 2) Sekolah diharapkan dapat menyediakan fasilitas yang mendukung kegiatan pembelajaran khususnya pada kemampuan berbicara, menyediakan boneka tangan yang unik dan menarik untuk setiap kelas dan mendukung upaya guru dalam meningkatkan aspek berbicara anak, 3) Peneliti Selanjutnya diharapkan dapat melakukan penelitian dengan media boneka tangan untuk meningkatkan kemampuan berbicara anak, masih banyak kekurangan dalam pelaksanaannya. Oleh karena itu hasil penelitian ini dapat menjadi motivasi bagi peneliti selanjutnya untuk melengkapi penelitian ini yaitu dengan mencoba menerapkan media boneka tangan untuk meneliti aspek perkembangan lain yaitu Kognitif, Sosem, Nam, Fismot dan Seni. Media boneka harus disesuaikan dengan ukuran tangan anak, agar anak mudah dalam memainkannya.

\section{Daftar Rujukan}

Arikunto, S. (2014). Penelitian Tindakan Kelas. Jakarta: Bumi Aksara Daryanto. 2013. Media Pembelajaran. Yogyakarta: Gava Media.

Dhieni, N., Fridana, L., Muis, A., Yarmi, G., \& Wulan, S. (2013). Metode Pengembangan Bahasa.Tanggerang Selatan: Universitas Terbuka.

Maharani, S. (2008). The use of puppet Shifting Speaking Skill From The Perspective Of Students' Self-Esteem. Universitas Sebelas Maret.

Mardiana, E. (2017). Pengaruh Penggunaan Mdia Boneka Tangan Terhadap Kemampuan Berbicara Di Kelompok A TK ABA 20 Kota Malang.

Musfiroh. (2005). Berceritera Untuk Anak Usia Dini. Jakarta: Depdiknas.

Nisa, K. N. (2018). Penerapan Permainan See And Show Untuk Meningkatkan Kemampuan Berbicara Anak Kelompok B Usia 5-6 Tahun Di TK Dharma Wanita Dewantara Kuniran Kabupaten Bojonegoro. Skripsi tidak diterbitkan. Malang:PG PAUD UM.

Peraturan Menteri Pendidikan dan Kebudayaan Republik Indonesia Nomor 137 Tahun 2014 Tentang Standar Nasional Pendidikan Anak Usia Dini. Luk Tsipil UGM. (Online) (http://luk.tsipil.ugm.ac.id/atur/bsnp/permendikbud137- 2014StandarNasionalPAUD.pdf), diakses 4 Desember 2018.

Sariguam, I. P. (2017). Efektifitas Pemanfaatan Media Boneka Tangan Terhadap Keterampilan Berbicara Peserta Didik kelas III Min Likuboddong Kecamatan Bontonompo Kabupaten Gowa.

Seefeldt, C. \& Wasik, B. (2008). Pendidikan Anak Usia Dini. Jakarta. Indeks.

Sulianto, J., Untari, A.F.M., \& Yulianti, F. (2014). Profil Cerita Anak Dan Media Boneka Tangan Dalam Metode Bercerita Berkarakter Untuk Siswa Sd. Jurnal Mimbar Sekolah Dasar. 1(2), 116

Sutrisna, D. (2017). Penerapan Model Tongkat Berbicara Berorientasi Karakter dalam Pembelajaran Berdebat. Semantik, 2(1), 12-29.

Supriyana, A. (2008). Berbicara. Tangerang Selatan:Universitas Terbuka.

Yunita, I. (2014). Meningkatkan Keterampilan Berbicara Menggunakan Metode Bercerita dengan Media Boneka Tangan pada Anak Kelompok A1 di TK Kartika iii-38 Kentungan. Depok, Sleman

Zuliana, A. (2018). Pemanfaatan Media Pembelajaran Damar Kurung Bergambar Untuk Meningkatkan Kemampuan Bercerita Anak Usia 4-5 Tahun Di TK Permata Bunda Sawojajar Malang. 